\title{
Parametric Modelling and Traditional Architecture: Improving the thermal comfort of the traditional courtyard house in Morocco
}

\author{
Khalid EL HARROUNI, Mouhcine BEN AICHA and Rime EL HARROUNI \\ Ecole Nationale d'Architecture, Laboratoire Energie, Durabilité et Maitrise des Ambiances, Rabat, Morocco
}

\begin{abstract}
The traditional courtyard house of the Mediterranean Basin has been viewed as a complex regulating system that creates a microclimate which historically worked, and still works, in a passive way to provide acceptable thermal comfort in summer. The internal courtyard is generally described as a positive factor that can moderate extreme outdoor climatic conditions. However, some researches have shown that the courtyard could become a negative factor from the energy efficiency point of view. For this purpose, this paper is based on a research study exploring sustainable characteristics of Moroccan traditional housing and its climatic adaptation, delving into the Rabat-Sale case study. A traditional courtyard model is used as a case study to analyze the indoor thermal comfort without using mechanical heating and cooling systems. The thermal behavior of the rooms surrounding the courtyard is analyzed under a temperate and humid climate of Rabat-Salé medina. The simulation modelling is carried out to analyze the effectiveness of different parameters to improve the indoor climate during summer and winter, including the façade orientation, the air infiltration, the surroundings, the ceiling height, the walls and roof/ceiling insulation and the shading devices. Tools for climatic design, Mahoney's tables, Givoni and Szokolay bio climatic diagrams have been also used to improve design strategies in terms of thermal comfort.
\end{abstract}

\section{Introduction}

The courtyard architectural type transforms a one or two facades building into a four solar orientations architecture. This is one of the main advantages of including a courtyard in the plant of a building inserted in a compact urban fabric. Whether to gain natural light, to create an open private space or to control the building thermal behavior, in the past the different types of courtyard house design used to follow the same principle: a central courtyard surrounded by rooms aligned with four interior facades.

The climatic behavior of the courtyard is especially important in arid areas that are characterised by hot, dry days and cool clear nights to radiate heat away to the sky, -climates with high temperatures during the day and low temperatures during the night and high temperature amplitude between the seasons-. Also for climates with cool but sunny days at lower latitudes where sun penetration is both: easy and welcome.

Some researches [1-2] have shown that the courtyard could become a negative factor from the climatic point of view. It can be hotter than its surroundings while, during the winter, the temperature difference remains smaller. It seems that for courtyard comfort, the worst climates are hot and humid, where little wind is available to relieve stuffiness; or cold and cloudy ones at higher latitudes, where little winter sun can penetrate to provide warmth.
Morocco has recently adopted new thermal regulation regarding energy efficiency in buildings [3]. The objective is to introduce minimum requirements in new residential and tertiary buildings in order to optimize their needs for heating and air conditioning, while improving their thermal comfort. The aim of this study is to simulate and to examine the thermal behaviour of a traditional courtyard house model under a temperate and humid climate in Rabat-Sale and to explain the findings, to compare them with similar research and to evaluate the architectural parameters that create a positive climatic adaptation to the environmental climatic conditions.

\section{General}

\subsection{The traditional house in the medina}

As a first phase of the research, we have explored the values of the medina within an analytical investigation of domestic and public spaces [4]. The traditional house can be defined by the following elements: the entrance, the central yard or patio and its surrounding rooms. These elements make it possible to describe the components of the domestic spaces (Fig. 1):

- the entrance: the corridor from the front door and into the house itself is often angled to minimize the view from outside; 
- the central yard and its surrounding rooms: the central courtyard has no roof or can have an opening in the roof. The ceiling height in the rooms varies from 3 to 5 meters and the rooms are often quite elongated. The use of the rooms is often non-specific and can be used for various purposes. The family life and the housekeeping take place in these domestic spaces, which can be used interchangeably for eating, sleeping, recreation and other domestic tasks. The rooms are organized around the patio which is the only space bringing in light and air to the rooms. There are usually very few or no windows facing the street, almost all the openings and windows are facing the inner courtyard.

The opening is important because it modifies the indoor climate and contributes to natural ventilation. It also works as a protection from sun and wind, walls are high enough to protect from the sun rays, that usually reach the courtyard until the afternoon. Then the warm air rises, and convention is created, ventilating the rooms. However, some studies have shown that the roof opening in the inner courtyard can be negative, especially in hot and humid climates. In hot humid climates, the temperature in the courtyard can be higher than outdoors because there is little wind and it can become stuffy inside the house.

Common traditional building materials are stone, earth, and wood, because of capillary effect, absorb water, which can then evaporate from their surfaces and thus hinder the interior air from being rewarmed by convection.

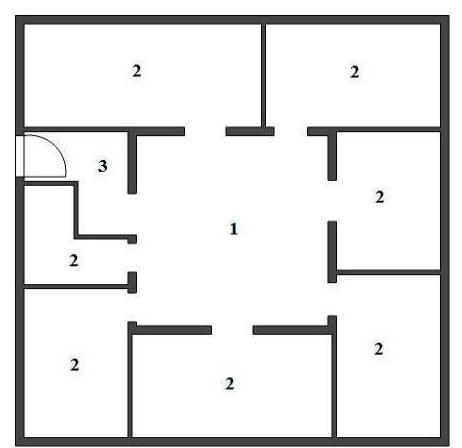

Fig. 1. A plan of a traditional house with the typical angle entrance [5].

The large residential area surrounding the city centre is formed by the composition of the residential quarters. A residential quarter is formed by the junction of neighborhood units along quarter streets. The residential area and the public area are enclosed all together by the city walls, and thus form a closed physical and social unit, the city or the medina.

A street in the medina is a long space between two walls which have no openings facing the street. The ratio between the height of the walls and the width of the street is big: about 10/1. Because of the streets depth and narrow, the sun rays can't reach the pavement or facades during the day.

\subsection{The problem}

Contemporary buildings and constructions in Morocco are often designed without taking the climate into consideration. Consequently, a great part of the built environment has a poor climate adaptation. However, as mentioned before, Morocco has now its thermal regulation and energy efficiency buildings code. The implementation of the thermal regulation is related to the building envelope with some technical specifications: $20^{\circ} \mathrm{C}$ in the winter for heating and $26^{\circ} \mathrm{C}$ in the summer for air conditioning. Those are the ideal temperatures for a good adequacy between thermal comfort of the room and energy consumption of the devices and equipments.

A building's indoor climate depends largely on the architecture and design of the building. Layout of the building, location and color of walls, location, size and orientation of windows and the buildings ventilation ability largely determines the climate in the building but also the building materials matters. Building materials can affect through thermal capacity and thermal conductivity.

One of the most frequent complains among the families living in the Moroccan traditional houses, regardless of the age of the house, involves moisture. The moisture that creates musty odors at the base of the walls, and the condensations that concentrate on the ceiling and other cold surfaces, affect approximately $50 \%$ [6] of the traditional houses.

Also extreme temperatures varying from winter to summer are a difficulty. These thermal discomfort problems are primarily due to the following factors: the climate, the thermal quality of the building materials, the ventilation and the renewal of the air, the orientation of the frontages and the lack of sun shining in the patio during the winter season.

The inquire housing in Morocco [6] confirms this thermal discomfort for the traditional houses that have the problem of low temperatures (77\% in Rabat-Salé). The moisture in more than $30 \%$ of the traditional houses affects the interior basement walls, and the ceiling during winter season.

\section{Case study}

\subsection{The site and the climate}

Rabat-Salé is located in latitude $34^{\circ} 03^{\prime} \mathrm{n}$, longitude $6^{\circ} 46^{\prime} \mathrm{w}$ and at an altitude of $75.3 \mathrm{~m}$ above sea level. The climate is temperate, Mediterranean climate, the Atlantic ocean has a cooling effect that transforms the climate along the coast into relatively mild.

The temperature data given by the local meteorological station show that the coldest month is January: the mean temperature is $12.5^{\circ} \mathrm{C}$ with an extreme minimum of $-0.5^{\circ} \mathrm{C}$. July is the hottest month with mean air temperature of $22.3^{\circ} \mathrm{C}$ and extreme maximum of $47.3^{\circ} \mathrm{C}$. The maximum and the minimum relative humidity are also given for every month, the maximum value is $96 \%$ and the minimum is $42 \%$. The maximum rainfall in Rabat-Salé is $110 \mathrm{~mm}$ in December. The 
maximum sunshine hours is evaluated to 13,85 hours per day in June; the highest global radiation is observed in June-July and the lowest in December.

\subsection{Hypothesis}

The aim of the study is to analyze the climatic behavior of the rooms surrounding the courtyard in a temperate and humid zone. It seems that one of the important factors is the ratio between the courtyard length to height of the rooms surrounding it. In hot and arid region for example [1], when the room walls are higher than the courtyard length, the patio climate is more comfortable than the outdoor climate, due to better shading that is provided by the surrounding walls. In contrast, it seems that when the length of the courtyard is longer than the height of its surrounding walls, the temperatures inside the patio are higher than the outdoor temperatures.

The internal courtyard can then affect the indoor climate. Unfortunately, this space is not studied because of the limitation of the computer program, DEROB-LTH [7] which cannot simulate an open space, a courtyard for example. Secondly, due to the lack of the courtyard climatic measurements during the summer and winter seasons -including the temperature, the humidity and the wind speed-, the main hypothesis of the present study is to consider the courtyard as an open space and to treat it as an outdoor space. Third, the DEROB-LTH software used in this study does not take into account the humidity of the air, which can be the principal source of the discomfort in the Rabat-Salé region.

\subsection{Analysis methods}

\subsubsection{Architectural bioclimatic tools}

Givoni/Szokolay bio climatic diagrams and Mahoney's tables [8-9] have been used in this study. There are still useful tools to give general considerations of the comfort zone with some recommendations for passive design of building.

According to the Rabat-Sale Givoni/Szokolay bioclimatic diagrams (Fig. 2-3), the comfort zone can be extended by using heating in January, in the rest of the winter months one can obtain a comfortable indoor climate with passive methods -internal gains-. The diagram shows that, because of the mild climate in RabatSale, ventilation is enough during the summer although the buildings must be designed with good ventilation possibilities and protection against solar radiation during the summer months.

Based on a diagnosis of some climatic indicators, the Mahoney tables give the performance specifications and the design recommendation for buildings in Rabat-Sale in order to have a best indoor climate:

-layout: orientation north and south (long axis east-west); -spacing: compact layout of estates;

-rooms should be double banked, with temporary provision for air movement;

-openings: medium openings, 25-40 \%;

-position of openings: in north and south walls, at body height on windward side, openings also in internal walls; -walls and floors: light, short time-lag, low thermal capacity;

-roofs: light, well insulated roofs.

The most important design parameters affecting indoor thermal comfort and energy conservation in building scale are building form and layout, building envelope design, building materials and optical and thermo-physical properties of the building envelope. Among these parameters, building envelope design, as it separates the outdoor and indoor environment, is the most important.

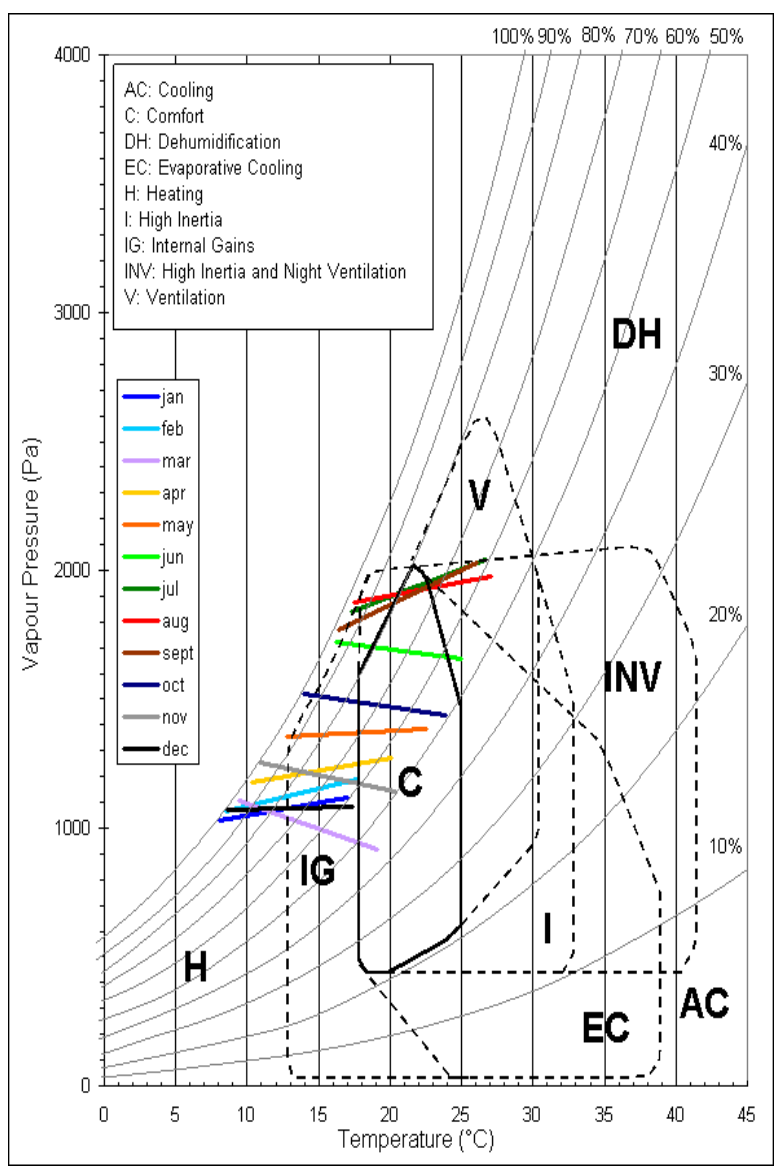

Fig. 2. Rabat-Salé Givoni bio climatic diagram.

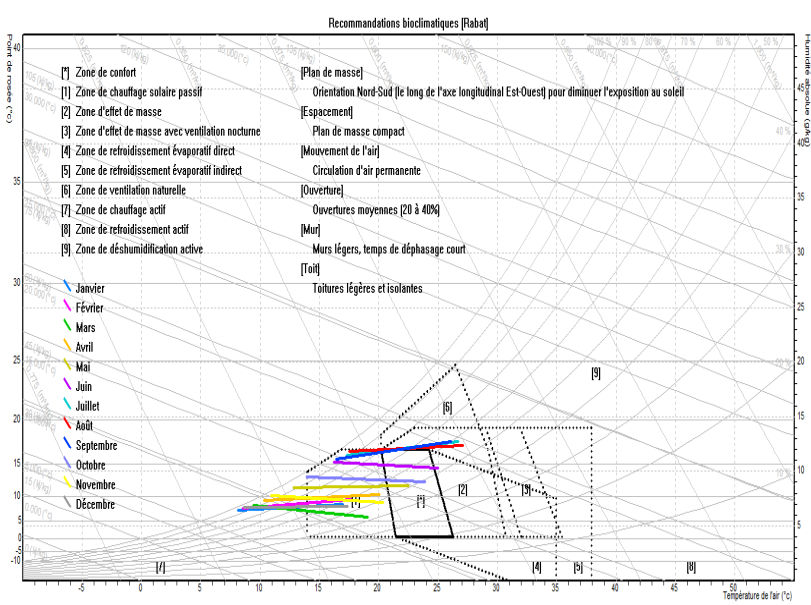

Fig. 3. Rabat-Salé Szokolay bio climatic diagram (Awrach). 


\subsubsection{Parametric and simulations modelling}

DEROB, which is an acronym for dynamic energy response of buildings, is a MS Windows based flexible simulation tool using a RC-network for thermal model design. It was originally developed at the numerical simulation laboratory of the school of architecture of the university of Texas at Austin. The DEROB-LTH modules are further developed to suit the local needs at the department of building science at Lund Institute of Technology. The calculations are performed in a dynamic way for each hour during a specified period of simulation, and they are influenced by climatic factors such as outdoor temperature, solar radiation and the sky temperature. Properties for the indoor climate of the building can be calculated based on these simulated results.

The Plot size surface of the traditional house model used as a case study is $88.0 \mathrm{~m}^{2}(11.0 \mathrm{~m}$ of width and 8.0 $\mathrm{m}$ of length) and the height is of $3.5 \mathrm{~m}$ but it is variable for simulation modelling.

Orientation of all façades (facing street, backyard or adjacent to other buildings) is also variable.

Regarding the openings, the total area of the window size is $2,16 \mathrm{~m}^{2}$ and the percentage of the façade is about $6.85 \%$. The total area of the doors is of $8,40 \mathrm{~m}^{2}$.

Figure 4 and Table 1 give the description of the traditional house model used as a case study.

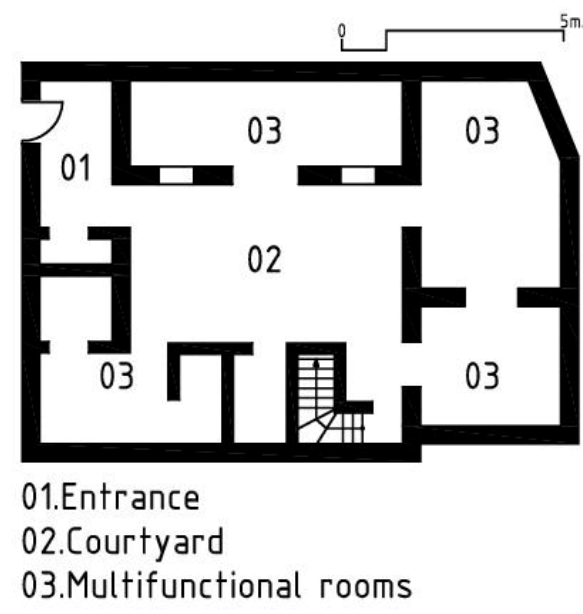

Fig. 4. Plan of the traditional house model.

Other data include air changes and internal heat loads during winter and summer (day and night ventilations) for both main rooms of the model house.

To perform DEROB modelling, the thermal behaviour of the volumes surrounding the courtyard is analyzed under a temperate and humid climate (Rabat-Salé) using passive design of building. Different simulations by DEROB-LTH were carried out using different parameters to improve the indoor climate. The operative temperatures in volumes 2 and 3 (DEROB model in Figure 5) are simulated during summer and winter using the climatic data and all information given in the project description.

\begin{tabular}{|c|c|c|c|c|c|c|c|}
\hline & \multicolumn{2}{|l|}{ NAME } & \multicolumn{2}{|c|}{$\begin{array}{l}\text { CONDUCTIV } \\
\text { ITY (W/MK) }\end{array}$} & $\begin{array}{l}\text { SPECIFIC } \\
\text { HEAT } \\
\text { (WH/KGK) }\end{array}$ & \multicolumn{2}{|c|}{$\begin{array}{l}\text { DENSITY } \\
\left(\mathrm{KG} / \mathrm{M}^{3}\right)\end{array}$} \\
\hline & \multicolumn{2}{|c|}{ RAMMED EARTH / PISÉ } & \multicolumn{2}{|c|}{0.80} & 0.20 & \multicolumn{2}{|l|}{2000} \\
\hline & \multicolumn{2}{|l|}{ EARTH } & \multicolumn{2}{|c|}{1.40} & 0.22 & \multicolumn{2}{|l|}{1300} \\
\hline & \multicolumn{2}{|l|}{ SAND } & \multicolumn{2}{|c|}{0.40} & 0.24 & \multicolumn{2}{|l|}{1700} \\
\hline & \multicolumn{2}{|c|}{$\begin{array}{l}\text { CLAY MIXED WITH } 40 \% \\
\text { SAND }\end{array}$} & \multicolumn{2}{|l|}{1.20} & 0.23 & \multicolumn{2}{|l|}{2000} \\
\hline \multirow{7}{*}{ 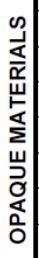 } & \multicolumn{2}{|c|}{ LIME PLASTER } & \multicolumn{2}{|l|}{0.80} & 0.24 & \multicolumn{2}{|l|}{1700} \\
\hline & \multicolumn{2}{|c|}{ PLASTER } & \multicolumn{2}{|c|}{0.35} & 0.30 & 900 & \\
\hline & LIME CEM & ENT PLASTER & 1.00 & & 0.24 & 1800 & \\
\hline & CEMENT N & ORTAR & 0.93 & & 0.29 & 1800 & \\
\hline & ZELLIGE / & CERAMIC & 0.80 & & 0.24 & 1900 & \\
\hline & WOOD & & 0.16 & & 0.70 & 700 & \\
\hline & MINERAL & VOOL & 0.04 & & 0.24 & 50 & \\
\hline & $\begin{array}{l}\text { EXISTING } \\
\text { ROOF }\end{array}$ & NALLS/FLOOR/ & $\begin{array}{l}\text { THIC } \\
\text { (MM }\end{array}$ & KNESS & NAME & & \\
\hline & FOUNDAT & & 500 & & EARTH & & \\
\hline & GROUND & & 15 & & LIME PLAS & ER & \\
\hline & & & 200 & & $\begin{array}{l}\text { CLAY MIX } \\
\text { SAND }\end{array}$ & DWITH & $40 \%$ \\
\hline & & & 15 & & CEMENT I & DRTAR & \\
\hline & & & 15 & & $\begin{array}{r}\text { ZELLIGE / } \\
\text { ABSOR }\end{array}$ & $\begin{array}{l}\text { ERAM } \\
\text { TIVITY }\end{array}$ & $\begin{array}{ll}C \\
40 \%\end{array}$ \\
\hline & $\begin{array}{l}\text { FAÇADE A } \\
\text { WALL }\end{array}$ & ND ROOM & 15 & & $\begin{array}{l}\text { LIME PLAS } \\
\text { ABSOR }\end{array}$ & $\begin{array}{l}\text { ER } \\
\text { TIVITY }\end{array}$ & $20 \%$ \\
\hline & & & 500 & & RAMMED & ARTH & \\
\hline & & & 20 & & $\begin{array}{r}\text { PLASTER } \\
\text { ABSOR }\end{array}$ & TIVITY & $20 \%$ \\
\hline & ADIABATIC & WALL & 500 & & MINERAL & $\mathrm{OOL}$ & \\
\hline & & & 250 & & RAMMED & ARTH $/$ & PISÉ \\
\hline & & & 20 & & $\begin{array}{r}\text { PLASTER } \\
\text { ABSOR }\end{array}$ & TIVITY & $20 \%$ \\
\hline$\Sigma_{0}$ & FLOOR AN & D ROOF & 15 & & ZELLIGE / & ERAM & \\
\hline ర్ & & & 15 & & CEMENT I & DRTAR & \\
\hline $\bar{n}$ & & & 150 & & $\begin{array}{l}\text { CLAY MIX } \\
\text { SAND }\end{array}$ & DWITH & $40 \%$ \\
\hline 8 & & & 25 & & SAND & & \\
\hline$\underline{\underline{4}}$ & & & 15 & & LIME PLAS & TER & \\
\hline 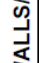 & & & 130 & & $\begin{array}{l}\text { WOOD } \\
\text { ABSOR }\end{array}$ & TIVITY & $60 \%$ \\
\hline 3 & DOOR & & 35 & & WOOD & & \\
\hline & $\begin{array}{l}\text { GLASS } \\
\text { TYPES }\end{array}$ & DATA TYPE & & $\begin{array}{l}\text { EMITT. } \\
\text { FRONT }\end{array}$ & $\begin{array}{l}\text { EMITT. } \\
\text { BACK }\end{array}$ & $\begin{array}{l}\text { RANS } \\
\text { IITT. }\end{array}$ & REFL \\
\hline$\sum_{0}^{\infty}$ & & $\begin{array}{l}\text { FRESNEL GLAS } \\
\text { NORMAL } \\
\text { TRANSMITTAN } \\
\text { AND REFLECTI }\end{array}$ & & $83.7 \%$ & $83.7 \%$ & $3.0 \%$ & $7.0 \%$ \\
\hline 号 & WINDOW & PANE & & GLASS & & HICKN & SS \\
\hline$\overline{\overline{3}}$ & TYPES & 1 & & CLEAR & & MM & \\
\hline
\end{tabular}

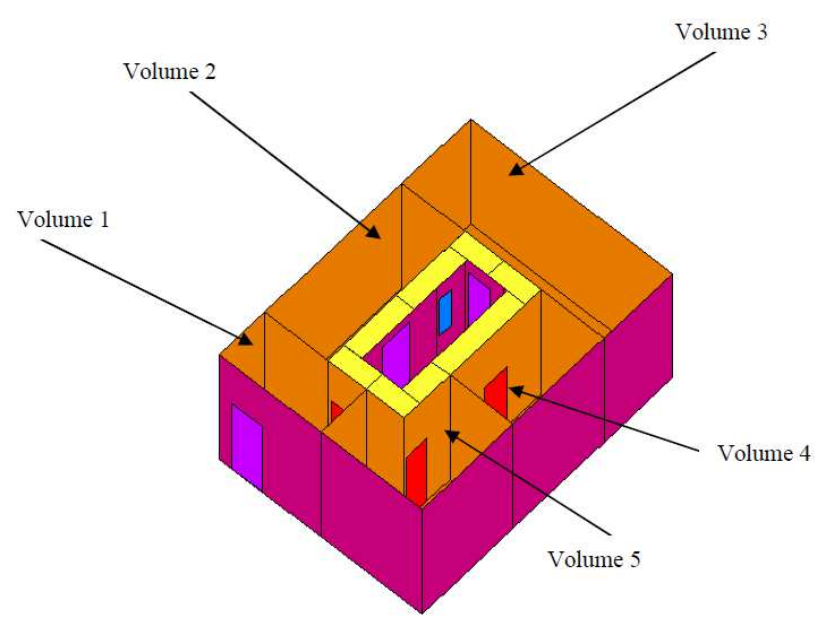

Fig. 5. DEROB model with 5 volumes

The operative temperatures in these rooms (Volumes 2 and 3) are first simulated during winter and the variants are:

Table 1. Description of materials. 
- The façade orientation: the orientation for solar access is important, especially in the winter. The four orientation cases, the façade facing to south (case 0), east (case 1), north (case 2) and west (case 3) were analyzed separately. Next simulation cases, the parameters were studied in combination in order to improve the indoor climate.

- The shading devices: the gallery in the traditional house is a covered space of the circulation and the transition between the courtyard or patio and the rooms. In winter, the galleries make it possible to circulate when it is raining. In summer, the galleries create shade and become an obstacle for the intense sun rays access. The shading device in the courtyard has a width of 0.7 $\mathrm{m}$ in the baseline case. In cases 4, 5, 6 and 7, the shading device is out in the courtyard.

- The ceiling height: the traditional house rooms have generally a high ceiling height (more than $3.0 \mathrm{~m}$ ). In the baseline case, the ceiling height $\mathrm{h}=3.5 \mathrm{~m}$, which is reduced to $h=3.0 \mathrm{~m}$ in cases $8,9,10$ and 11 .

- The surroundings: the site layout in terms of the width street and the surroundings height were analyzed in combination with the orientation. The surrounding variation facing building height and the small width street are examined in the case 12 .

- The roof/ceiling and walls insulation: thermal insulation of the roof and the walls is also important for better comfort. Composite insulating panels (woodwool/mineral-wool) for walls and wood-wool slabs for roof (Table 2) were used (cases 13 and 14).

- The air infiltration: the ventilation is an important factor for comfort, especially during the night and day ventilations. The air change hour (ach) is reduced from 4 to 2 ach during evening (between 19 and 24), and from 3 to 1 ach during night (between 01 and 07). This corresponds to the case 15 .

Table 2. Walls and roof thermal insulation.

\begin{tabular}{|c|c|c|c|}
\hline $\begin{array}{c}\text { Insulation } \\
\text { material }\end{array}$ & $\begin{array}{c}\text { Conductivity } \\
(\mathrm{W} / \mathrm{mK})\end{array}$ & $\begin{array}{c}\text { Thickness } \\
(\mathrm{cm})\end{array}$ & $\begin{array}{c}\text { Density } \\
\left(\mathrm{Kg} / \mathrm{m}^{3}\right)\end{array}$ \\
\hline $\begin{array}{c}\text { Composite } \\
\text { Insulating panel } \\
\text { (wood wool / } \\
\text { Mineral wool) }\end{array}$ & 0.04 & 5 & 200 \\
\hline Wood wool slab & 0.07 & 3 & 300 \\
\hline
\end{tabular}

The winter parametric modelling process starts from case 0 which is the baseline case and consists in varying the above parameters to reach case 15 which is the best possible solution obtained by reducing the air changes hour during evening and night. Combining case 10 corresponding to reduction of the ceiling height with case 14 using roof and walls insulation.

The operative temperature in the volumes 2 and 3 (the main rooms of the house) are displayed in figures 6-7 for the baseline case (case 0) and the best solution (case 15).

The winter indoor climate has also shown only small difference between the orientation cases (façade facing to the south, east, north and west) and the shading devices of the courtyard. Indeed, these orientations are equal for this house model while north orientation combining with the ceiling height reduction give higher indoor temperatures. The north orientation in the present case means that the rooms (volume 2 and volumes 3 ) have west and north windows.

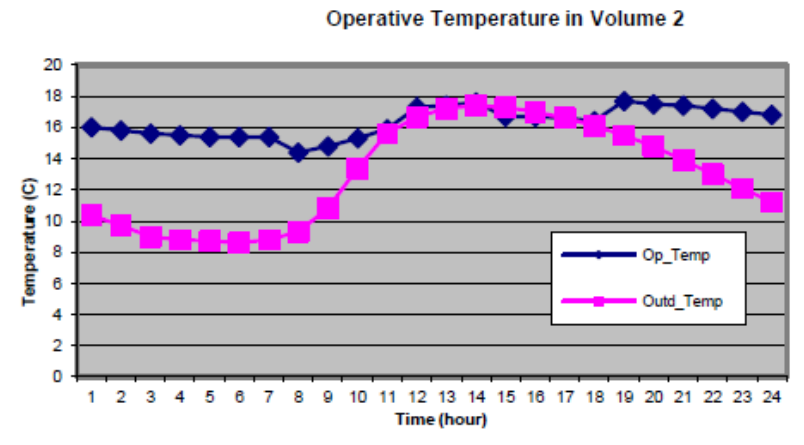

Fig. 6. Operative temperature in volume 2 during December (case 0)

The optimal orientation, the façade facing to the north, is then selected in order to have a moderate indoor climate in both main rooms.

Thermal insulation of the roof and the walls is important for a better comfort. We considered walls and roof ceiling with additional insulation: an inner insulated layer of $50 \mathrm{~mm}$ using composite insulating panels (wood wool / mineral wool) for walls and an outer insulated layer of $30 \mathrm{~mm}$ of wood wool slabs for the roof. In wintertime, this type of insulation gives a better performance than the previous cases.

Another important factor related to comfort is the air infiltration, especially the day ventilation which is useful to improve the indoor climate during the winter. Operative temperatures in figure 8 show the effect of the ventilation when reducing the ach during evening and night. An important increasing of 3 degrees is observed. Finally, the case 15 is the best possible solution obtained in the winter parametric modelling process.

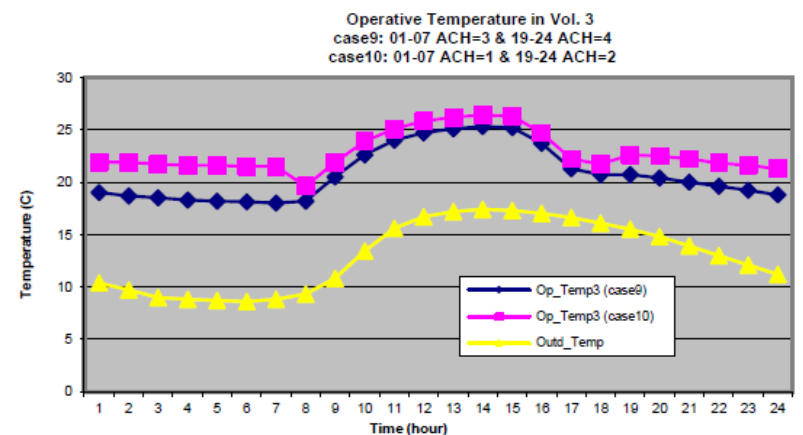

Fig. 7. Operative temperature in volume 3 and air changes hour reduction during December (case15) 


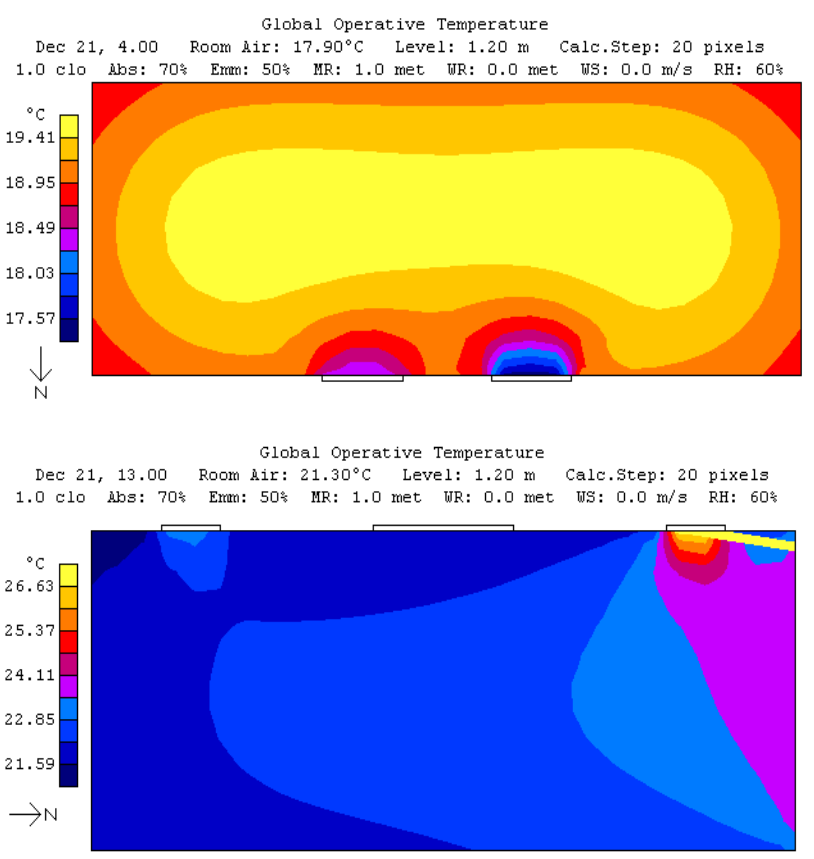

Fig. 8. Global operative temperature in volumes 2 and 3 during night and day times (winter)

The operative temperatures in volumes 2 and 3 are then simulated during summer and the influence of the following parameters is studied: the ceiling height (case 17), the shading devices of the courtyard (case 18) and the air infiltration in terms of day (case 19) and night (case 20) ventilations. During winter, the main rooms should be closed at night and open during the day to maximize the indoor temperatures. The reversed strategy (night ventilation) should be used in the summer

Case 20 seems to be the best possible solution obtained by increasing the ceiling height and the dimension of the shading device in the courtyard and by adopting the option of the night ventilation.

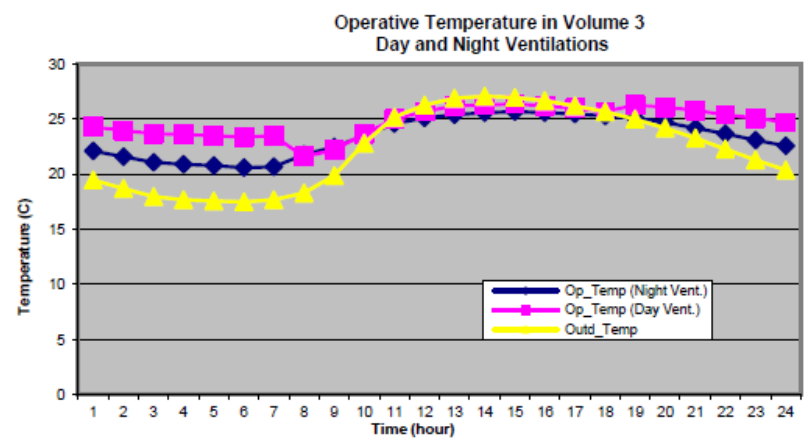

Fig. 9. Operative temperature in volume 3 and ventilation, August (cases 19 and 20)

\section{Conclusions}

We can conclude through all simulations that the courtyard can be considered a positive factor in the passive design of dwellings in the Rabat-Sale region.

In order to keep traditional courtyard house in this area, while improving its energy efficiency and meeting the new energy regulation requirements, some strategies should be taken into account by designers:

-Lengthening the courtyard in the axis parallel to the north and south façades.

-Increasing (more than $3.0 \mathrm{~m}$.) the ceilings height in the south and west oriented internal rooms.

-Diminishing (less than 3.0) the ceilings height in the north and east oriented internal rooms.

-Increasing the insulation in the roof, north and east internal facades.

-Moderating the insulation in the south and west internal facades.

As general considerations to be implemented by owners:

-Reducing the air changes hour during evening and night during the winter, maintaining only the minimum time required for the air renovation and moisture ventilation.

-Increasing the dimensions of the shading devices of the courtyard during the summer.

-Increasing the night ventilation as much as possible and a low air changes rate is recommended during daytime in the hot season.

\section{References}

1. Y . Etzion, The Thermal Behaviour of Non-Shaded Closed Courtyard in Hot, Arid Zones, Architectural Science Review, 33, 79-83 (1999)

2. I.M. Meir and D. Pearlmutter, Attached Courtyard Asset or Debit, Proceeding of International Conference on Energy and Buildings in the Mediterranean Area, Saloniki, Greece, 245-252 (1992)

3. Royaume du Maroc, Bulletin Officiel, Décret $\mathrm{N}^{\circ}$ 2.13.874 Approuvant le Règlement Général de Construction Fixant les Règles de Performance Energétique des Constructions et Instituant le Comité National de l'Efficacité Energétique dans le Bâtiment, 6306, 4256-4269 (2014)

4. A. Abarkan and A.M. Salama, Courtyard Housing in Northern Africa: Changing Paradigms, ENHR 2000 Conference, Gavle, Sweden, Housing in the $21^{\text {st }}$ Century, Fragmentation and Reorientation, 26-30 (2000)

5. T. Brunzell and S. Duric, Moroccan Architecture, Traditional and Modern - A Field Study in Casablanca, Morocco, Bachelor Thesis, LTH School of Engineering, Housing Development \& Management, Lund University (2012)

6. Royaume du Maroc, MATEUH, SEH/DPI/OH, Enquête Logement 2000, L'Observatoire de l'Habitat (2000)

7. H. Kvist, DEROB-LTH for MS Windows, User Manual, Department of Building Science, Lund Institute of Technology, Lund University, Sweden (1999)

8. B. Givoni, L'homme, l'Architecture et le Climat. Éditions du Moniteur, Paris (1978)

9. S.V. Szokolay, Introduction to Architectural Science. The Basis of Sustainable Design. Architectural Press (2008) 